\title{
Sustainable Development
} Goals Must Consider Security, Justice and Inequality to Achieve Social Justice

Security and social justice have a crucial role to play in the newly proposed Sustainable Development Goals (SDGs). The goals, which aim to establish a safe, sustainable and just society for all, require a truly transformative approach, one that places inclusivity, safety, equity and justice at the centre of a global pursuit for sustainable development. However, some United Nations (UN) member states are reluctant to securitise the sustainability agenda, and are advocating against their inclusion in the SDGs. The reality is that insecurity and inequality are at the crossroad of security and sustainability, making them significant issues to overcome. This Policy Briefing argues that a reframing of security and justice around a social justice lens would create space to address the interlinkages between sustainability and security and justice.

Insecurity and injustice are daily facts of life for many people around the world, especially the poor. According to the World Bank, two-thirds of the world's poorest people and almost the same proportion of the malnourished live in regions affected by conflict. Current trends indicate that extreme poverty will become increasingly concentrated in so-called 'fragile states', so addressing injustice and insecurity is fundamental to sustainability and poverty reduction.

Despite widespread recognition of the linkages between peace, governance, and development, several UN member states remain averse to including these issues in the post-2015 development agenda. Brazil in particular has expressed opposition to the inclusion of a standalone goal on 'peaceful societies' as well as many of the proposed peace-related targets within the SDGs. Brazilian diplomats are worried that a focus on peace, security, justice, or governance could securitise the development agenda and reinforce a unilateral worldview. Along with other countries, Brazil is concerned about infringing on national sovereignty, and that shifting official development assistance to fragile and conflict-affected states would potentially crowd out other issues such as poverty, climate, and sustainability.

The Western interventionist agenda in the Middle East and sub-Saharan Africa under international norms - such as the responsibility to protect - has led to many suspicions about developing new norms around individual security entitlements.
This has led to further concerns over including security and justice in the SDGs. For example, designing indicators specific to conflict and violence, such as reducing violent deaths per 100,000 inhabitants - as suggested by some - is unrealistic. Indeed, how could the international community hope to control or contain the origins of conflict and violence? More importantly, current framing and approaches to security, development and justice could dilute the developmental focus of the post-2015 agenda.

Flaws in current approaches to security, justice and development

Over the past 15 years the three key approaches to security, justice and development have focused on state building, transitional justice and hybridity.

Many donors approach 'security and justice delivery in fragile states' through the lens of democratic governance and state building. While states have an irreducible role in the delivery of justice and security services, these approaches need to be balanced with the realities of each particular state, rather than trying to reproduce Western ideas of the ideal state. The framing around fragility and failed states creates suspicion of Western interventionist agendas among countries, especially the BRICS (Brazil, Russia, India, China and South Africa). Furthermore, donor programmes with technical approaches that focus on strengthening state institutions' capacity show little evidence that this actually improves citizens' experiences of security and justice. 
Transitional justice has blossomed since the end of apartheid and the creation of the truth and reconciliation commission in South Africa, and subsequent other commissions in sub-Saharan Africa and Asia. By trying to achieve accountability and recompensing victims, it provides recognition of the victims' rights, promotes civic trust and strengthens the democratic rule of law. However, this puts too much faith in the law as the best method of dealing with the aftermath of political violence, especially if the government was originally implicated in the violence. Additionally, the catharsis that victims experience in being heard, hearing the truth about war crimes and learning of the associated sentencing, while valuable, is limited. Truth commissions and criminal prosecutions on their own are not enough to foster social repair and might even hamper much-needed social and political change.

Finally, more recent approaches have looked at the role of hybrid political orders, where a diverse set of institutions - public and private, traditional or more formal, including militias, vigilantes, warlords and other non-state actors may provide the only viable means of establishing security and providing access to justice. However, there is a real danger that this approach could simply give legitimacy to inequitable and sometimes violent local-level structures, unless social justice or tackling inequality is explicitly considered.

\section{Security and social justice}

Dominant approaches ignore the need for social justice, which may have been at the origin of conflict and violence. Generally equated with the notion of equality and distribution, and commonly present in mainstream discourse, social justice remains a complex and contested concept. However, when reformulating debates around a transformative sustainable approach, security and justice become central to the SDGs. Including them would put inequality back into policy debates, which currently focus overwhelmingly on the politics of statehood.

Applying a social justice lens to security, justice and development debates would bring into focus how politics is inseparable from its economic foundations, and most notably inequality. Indeed, current policies show that in many post-conflict countries, structural injustice continues, perpetuated by an underlying structure of political power that remains largely unaltered since the end of the war. Of course, the human security agenda addresses some of the concerns that should be reflected in the SDGs' goals, but fails to deal with larger structural issues linked to inequality.

\section{Policy recommendations}

If the SDGs are to achieve their aim of establishing a safe, sustainable and just society for all, the post-2015 framework should place security, justice, and inequality at the centre of a global pursuit for sustainable development. Progress towards this could be achieved by:

- Creating a new UN discourse around peace, security and justice, with security as an entitlement.

- Developing a number of goals to address inequality and discrimination in terms of income redistribution, resource management and social, economic and political inclusion to address the underlying issues that drive violence.

- Establishing an objective that enables citizens to hold states accountable, by:

- Securing rights to land and property for men and women.

- Ensuring citizen participation in monitoring the effective provision of essential services such as healthcare, water and education.

- Creating affordable and timely access to justice institutions and legal aid services.

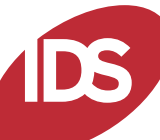

Institute of Development Studies

IDS Policy Briefings are published by the Institute of Development Studies and aim to provide high quality analysis and practical recommendations for policymakers on important development issues. To subscribe: www.ids.ac.uk/idspolicybriefings

Further reading

Saferworld et al. (2012) Bringing Peace into the Post-2015 Development Framework: A Joint Statement by Civil Society Organisations

Allouche, J. and Lind, J. (2014) 'Beyond the New Deal: Global Collaboration and Peacebuilding with BRICS Countries', IDS Policy Briefing 59, Brighton: IDS

\section{Credits}

This IDS Policy Briefing was written by IDS Research Fellow, Jeremy Allouche. It draws on research by Dr Allouche and colleagues working on the IDS Addressing and Mitigating Violence programme. The programme is supported with UK aid from the UK Department for International Development.

The opinions expressed are those of the author and do not necessarily reflect the views of IDS or the UK government's official policies.

Readers are encouraged to quote and reproduce material from the IDS Policy Briefing series. In return, IDS requests due acknowledgement and quotes to be referenced as above.

AG Level 2 Output ID: 68

(C) Institute of Development Studies, 2015 ISSN 1479-974X 